\section{THE WAR AND BRITISH CHEMICAL INDUSTRY.}

WING to the urgency of the aniline dye question and the discussion which has been taking place on the Government scheme, it has been thought expedient to issue part iv. of a memorandum dealing with the entire question of the "War and British Economic Policy." It is published by Messrs. P. S. King and Son, of Westminster, and a brief summary of it is given in the Chemical Nerws of February 26. British industries use annually dyes to the value of nearly 2,250 ,oool., of which about $1,75^{\circ}$, oool. come from Germany, about $\mathrm{5}_{5} \mathrm{O}, \mathrm{oool}$. from Switzerland, and only about 200 ,oool. are of British home production. Aniline dyes constitute an indispensable material in many branches of the textile, leather, paper, and other industries, and the annual value of the goods in which they are an essential or important part is estimated at $200,000,000 l$.

The opinions of a large number of firms interested in the use or manufacture of aniline dyes are given in the memorandum in question, and emphasis is laid on the fact that the dependence upon German supplies is so great that the present capacity of British dye works is totally inadequate to fill the gap. During the past few weeks the Government scheme has formed the subject of numerous articles and letters to the Press, and a brief review may here be given of these, so far as they deal with the general question of the relationship between science and industry in this country, and ignoring all problems of, a political nature, such as the question of the necessity for a protective tariff for the proposed new industry.

Prof. Armstrong, in a letter to the Morning Post of February 27, after considering the report of the debate on the Government dye scheme in the House of Commons, concludes that the "situation is an almost hopeless one owing to the lamentable ignorance of our public men of matters scientific." He illustrates this want of knowledge by a criticism of Mr. Runciman's recent pronouncement that in organising the new scheme the Government "had at their elbows two, at least, of the greatest chemists of Europe," a description which, it is contended, will "scarcely pass muster."

If the production of dyes is to be taken in hand seriously, and the foundation laid of a permanent industry, men must be chosen to manage the enterprise who are as able as was my dear old friend, now deceased, Dr. H. Caro, who played so great a part in the development of the Badische Anilin Company, or as his eminent successor, Prof. Bernthsen is, or as is Prof. Duisberg, who has brought the Bayer Company to its present proud position, and now dominates the whole industry. . . We have in our ranks men of their type who would be immediately available. But apparently the advisers of the Government want subordinate intellects, not leaders.

Dr. M. O: Forster, in a characteristically ironical letter to the same journal, points out that the establishment of an indigenous dye industry "is, has been, and ever will be as much a question of education as of trade. Education of legislators,
Government officials, manufacturers, and merchants." It was to have been wished that before taking any steps towards organising the new scheme, every member of the Cabinet, together with the other Ministers, "could have been transferred bodily to Ludwigshafen and personally conducted through the Badische Anilin- und SodaFabrik." Dr. Forster depicts with considerable humour the astonishment that Mr. Runciman and the others might have expressed at the organisation and laboratories of this firm, and especially on finding some actual chemists on the directorate.

Several columns are devoted by the Financier of February 12, 23, and March 12 to interviews with Mr. W. P. Dreaper, who, as chemist to the Silk Association, speaks with some authority on the practical side of the question. Mr. Dreaper also most strongly emphasises the necessity that the board of the proposed company should contain a scientific representation, and the absolute importance of securing the best scientific knowledge which is available. He protests against the policy of training chemists of the "second class," of which Mr. Runciman seems to consider that we have an insufficient supply, and against the general lack of understanding which exists amongst manufacturers as to what a chemist is "owing to the demand that has sprung up in certain directions for the $70 l$. per annum variety."

The lack of appreciation in this country of the services of the chemist and the absolute ignorance on the part of the Government of what remuneration should be given him is admirably illustrated by the letter of Sir William Tilden in the Chemical News of February 26, protesting against the salary offered by the Royal Arsenal, Woolwich, to assistant chemists in the inspection department. At a time when the nation is spending $1,250,000 l$., and will soon be spending $r, 750,000 l$., per diem on maintaining our army in the field, the utmost that the War Office can afford to give a chemist who has "had a thorough training in inorganic and organic chemistry," and is "a university graduate or member of the Institute of Chemistry," is the sum of $2 l$. os. $6 d$. per week! Such an advertisement "gives one to think," and is, indeed, a striking object lesson of the fact which Prof. Armstrong deplores- "we have had no public use for science in our country, and we are blind to our needs and as to our opportunities."

The whole question of the utilisation of science in industry is indeed closely wrapped up with that of the miserably insufficient remuneration given in the majority of cases to science and scientific workers, which Sir Ronald Ross has so strongly emphasised in recent numbers of Science Progress. So long as the prospects of the young chemist and the remuneration that he receives are of the order indicated in the above advertisement there is little hope of developing in this country industries that require the services of large numbers of highly-trained scientific workers.

It is interesting to find a politician like $\mathrm{Mr}$. L. G. Chiozza Money, M.P., emphasising the NO. 2370, VOL. 95] 
same lesson in an article in the March Fortnightly Review on "The War and British Industry." Mr. Money comments that "we have been content to leave the development of many old industries and the establishment of many new industries to foreign hands," owing to our "normal" disregard of science.

Let us not deceive ourselves into believing that "science" or "chemistry" affects a limited number of subsidiary industries. There is no industry in the world, from building construction to coke-making, from artillery construction to the making of explosives, from dyeing to leather tanning ... which has not been in recent years turned inside out by science and invention. We have been content in too many matters to let the world go by us.

Even in the matter of preparation for war Mr. Money, quoting from the address delivered before the Mathematical Association on January 9 by Sir George Greenhill (see NATURE, January 21, p. 573), gives a melancholy contrast between the conditions under which German and British artillery officers have been trained in their science at the Military Technical Academy of Berlin and at Woolwich.

The neglect of science in industry and in public affairs, which is characteristic of this country, culminated in the prospectus of British Dyes (Limited), on the board of which science is entirely unrepresented. The opinions of Sir Henry Roscoe and Sir William Ramsay on the scheme, expressed in the columns of the Times, have already been given in Nature (March II, p. 4I), whilst Prof. Armstrong, in the Morning Post (March I3), considers that "our fate as makers of dyes is sealed." The failure of the scheme to attract sufficient capital from investors to justify the directors of the company in proceeding to allotment was referred to last week (p. 94). A meeting of representatives of the textile and dyeing trades was held at Manchester on March 24 to consider the position, and a resolution was adopted in favour of proceeding with the company if certain modifications were made in the business part of the programme. There is no doubt as to the national necessity for such work as the Government scheme is intended to promote, but to expect that a company without a single industrial chemist upon its board of directors will be able to compete with the highly organised coai-tar colour industry of Germany is to show complete want of understanding of the scientific problems which must be faced if permanent success is to be assured.

How little Germany fears competition in this field in the future from English manufacturers, even though aided by the resources of the State, can be gathered from an admirable article by Prof. O. N. Witt in the Chemiker Zeitung for February 13. In this article are given the real reasons why Germany has been able to outstrip all competition and to secure practically a monopoly, and why the foundations of the industry are so solidly based that the prosperts of the British scheme having No. 2370 , VOL. 95] anything like a permanent success seem altogether illusory. It must be remembered that the German chemical industry (with one or two exceptions) has never received any protection whatever from tariffs. How futile such protection as that afforded by patent laws can be in comparison with the results obtained by the organisation of science in the service of industry is emphasised by a report to Congress, which is reprinted in the Chemical News of March 5. In the United States a 30 per cent. duty on some coal-tar dyes for more than thirty years has not produced a real coal-tar dye industry. Germany, on the other hand, has succeeded because she has placed science on a sound business footing, of which the fair remuneration of the scientific worker has been a striking feature. The part played by the German banks, often with men of considerable scientific attainments on their boards, in developing German industry is emphasised by $\mathrm{Mr}$. W. P. Dreaper in an article on Industrial Research in the Financier of March I2.

Germany, in short, has succeeded in the past because she deserved to succeed. Not only has she organised scientific effort on the manufacturing side, but she has organised equally effectively her commercial relations with foreign countries. This side of the question, which has played no small part in attaining the final result, is dealt with in the current Bulletin of the Société d'Encouragement (vol. cxxii., p. 33), by M. Lindet, who gives as an example an account of the methods adopted by Germany in Rumania.

The Germans present to the Rumanians objects specially manufactured to satisfy the local requirements, sold at a price which is lower than ours because they are manufactured more cheaply and because they bear lower charges for transport. The German and Austrian merchants and manufacturers interested in Rumanian business have formed a syndicate with its representative at Bucharest. They obtain in this way facilities for transport in common which we do not possess. They have at Bucharest banks which allow long-date credits, and they have representatives and travellers who without intermission pursue their clients. They advertise widely, and have inaugurated at Bucharest a museum of their goods.

It is an organisation of this kind, highly developed on both the manufacturing and commercial sides that we have to prepare to face in the future, after the war has ended and Germany is left free to resume her usual activities.

$$
\text { DR. A. S. LEA, F.R.S. }
$$

THE ranks of those who took part in founding the Cambridge Physiology School grows thin. But a few months ago we recorded the death of Dr. Gaskell. We have now to record the death, on March 23, of Dr. Arthur Sheridan Lea at sixty-one years of age.

Lea entered Trinity College, Cambridge, in I 872 , he became Foundation Scholar of the College, and in 1875 he took a First Class in the 